\title{
Implementation Strategy of the Mutanaqishah Musyarakah Academic at Home Ownership Financing in Sharia Banks in Indonesia
}

\author{
Tuti Anggraini' ${ }^{1}$, M. Yasir Nasution ${ }^{2}$, Andri Soemitra ${ }^{3}$ \\ ${ }^{1,2,3}$ Universitas Islam Negeri Sumatera Utara, Indonesia \\ tutianggraini@gmail.com
}

\begin{abstract}
This research aims to: (1) Knowing the obstacles faced in implementing the Mutanaqisah Musharaka Financing (2) The solutions taken to overcome these obstacles; and (3) the right strategy to apply musyarakah mutanaqisah financing. This study uses the Analytic Network Process (ANP) method and the assistance of Super Decision software. ANP is carried out in three stages, namely: first, in-depth interviews with Islamic banking experts and practitioners to identify the factors that influence the minimum amount of musyarakah mutanaqisah. Second, the results of the first step are used to create an ANP framework and a questionnaire addressed to Islamic banking experts and practitioners; and third, ANP analysis to determine the best priorities, solutions and strategies for implementing Musyarakah mutanaqisah financing in Islamic banking.The results showed that: (1) The constraints faced by Islamic banking in implementing Musyarakah Mutanaqisah financing for Islamic banking KPRS financing can be divided into two, namely internal and external problems. Internal problems stem from internal banking, banking human resources, and musyarakah mutanaqisah financing products. External problems originate from customers, authorities, and Islamic banks. The most priority problem faced is internal problems, namely human resources (HR) associated with low knowledge and skills about the MMQ contract. Meanwhile, the most dominant external problem is Islamic banking with a lack of insight into the MMQ contract. (2) The solutions given in determining the financing strategy for the musyarakah mutanaqisah are divided into two, namely internal and external solutions. The most priority solution comes from internal solutions, namely product solutions in the form of Islamic banking that must vary the contract, especially for the $M M Q$ contract; and (3) The alternative with the most priority in determining the financing implementation strategy with the musyarakah mutanaqisah contract in Islamic banking is the Socialization and Education Program, followed by Contract Optimization, Portfolio Development, Image Strengthening, MMQ Segmentation Mapping, and $M M Q$ financing market segmentation.
\end{abstract}

Keywords

economy, strategy, musyarakah mutanaqishah contract; Islamic bank

\section{Introduction}

Musyarakah Mutanaqishah is a contract in the form of investment and financing adopted by companies and financial institutions. This form of financing emerged and spread, especially in companies as a means of financing and investing together with murabaha, ijarah and other financing tools. The increasing popularity of musyarakah mutanaqishah as the principle for regulating Islamic home financing products in Islamic banks has resulted in a 
paradigm shift in the contracts for conducting Islamic mortgage transactions. Islamic banking is a bank institution that is managed with Islamic principles (Tarigan, 2020).

This paradigm shift begins with the spirit to avoid usury, which is the pulse of banking practice, which comes from the interest rates that customers must pay on debt transactions that apply in banking practice where the prohibition of usury in the Koran has a deep meaning in wanting a change in the operational paradigm of the banking system, not just a transactional transformation. But it turns out that Islamic banks are less interested in offering mudharabah products fully, this is due to several things that need to get their own solutions (Rahmati, 2018). The agenda of building the economy of the people, welfare of the community, and a just economy is a mission that should be carried out by Islamic banks. This paradigm shift is what customers want and hope for in Islamic banking.

In the conventional banking paradigm, the relationship between banks and customers is in the form of creditors and borrowers. As the owner of the funds, the bank has transferred all risks to the borrower. The borrower, on the other hand, has transferred all collateralized assets which can be transferred to the bank at any time. The bank's dominance in this system makes customers often in a weak position. In the Islamic banking paradigm, the relationships that are built are partnership, participatory, and share risks and benefits in the form of buying and selling relationships (ba'i murabahah, ba'i Salam, and ba'i istishna '), leasing (ijarah) or leasing. (ijarah muntahiya bi at-tamlik), joint ventures in the form of mudaraba and musharakah and musyarakah mutanaqishah, or the provision of services in the form of a guarantee (kafalah), representatives (wakalah) and others. All of these transactions require an exchange of money and goods or services, equality, rights and obligations. By carrying out this paradigm, the relationship between banks and customers is mutually beneficial for the sake of mutual welfare. There is no exchange of money for cash with additional interest. There is no one-sided domination or exploitation. Understanding empowerment is directed more towards improving the ability of a society to be self-sufficient, can control its future and can even influence others (Saleh, 2019).

This paradigm shift is a breath of fresh air for customers, especially Muslims in Indonesia, to conduct financial transactions using Islamic banking with a variety of contracts offered. However, based on the market share of Islamic banking in Indonesia as of September 2020, which is only $6.24 \%$, with the majority of financing in Islamic banking still being funded by the murabahah or buying and selling-based contract, which is around $45.80 \%$, accompanied by the Musyarakah agreement, 45, 05\%, for mudaraba around 3.22\%, ijarah $2.46 \%$, Qardh 2.62\%, istishna'0.61\% Others around 0.24\%.

\section{Review of Literatures}

\subsection{The Theory of Al-Ghunmu Bi Al Ghurmi and Al-Kharaj Bi Al-Dhaman}

The basic concept in Islamic banking is the concept of sharing, both profit and loss sharing. The general principle is that anyone who wants to get a return on his savings must also be willing to take risks. Islamic banks will also share the company's losses if they want to get a return from their capital. This is in line with specific fiqh rules in the field of muamalah or transaction which readsal-kharaj bi al-dhaman (business results appear together with costs / rights to get results due to the obligation to bear losses), and always be connected with the rule of al-ghunm bi al-ghurm (profit comes with risk / risk accompanies benefit).

The Black-Litterman model is a mathematical model for portfolio allocation developed in 1990 at Goldman Sachs by Fischer Black and Robert Litterman, and published in 1992. This model seeks to address the problems institutional investors face in applying modern portfolio theory to practice. The model starts with an asset allocation based on equilibrium 
assumptions (the asset will perform in the future as it did in the past) and then modifies that allocation taking into account the investor's opinion of the asset's future performance.

Asset allocation is a decision faced by an investor who must choose how to allocate his portfolio to a number of asset classes. In order to calculate the portfolio of intersections and the maximum investment, separate risky assets from risk-free assets. Investors need accurate estimates of the expected returns, variance and covariance assets. In practice this can be very challenging, especially if many assets have been considered. Furthermore, mean variance optimization is very sensitive to the expected return estimates.

In principle Modern Portfolio Theory (Markowitz's mean-variance approach) offers a solution to this problem once the expected returns and covariances of the assets are known. While Modern Portfolio Theory is an important theoretical advance, its universal application faces a problem: although the covariance of some assets can be adequately estimated, it is difficult to produce reasonable estimates of expected returns.

Black - Litterman solves this problem by not asking the user to enter an estimate of expected return; instead of assuming that the initial expected return is whatever is required so that the equilibrium asset allocation equals what we observe in the market. The user is only asked to state how his assumptions about the expected return differ from the market and to state his level of confidence in the alternative assumptions. From this, the Black-Litterman method calculates the desired (mean-variance efficient) asset allocation. In general, when there is a portfolio constraint for example, when short sales are not allowed the easiest way to find the optimal portfolio is to use the Black - Litterman model to produce a favorable return expected for the asset.

\subsection{Transaction Cost Theory}

Transaction Cost Theory or transaction cost analysis is the application of an economic perspective to explain global transactions. Douglass North states that there are four factors consisting of transaction costs, namely, measurement, enforcement, ideological attitudes and perceptions, and market size. Measurement refers to calculating the value of all aspects of the goods or services involved in a transaction. Enforcement can be defined as the need for a third party who is unable to ensure that none of the parties involved in the transaction deny part of the agreement. The first two factors emerge in the concept of attitudes and ideological perceptions, the third aspect of transaction costs. Ideological attitudes and perceptions encapsulate each individual's set of values, which influence their interpretation of the world. The final aspect of transaction costs, according to North.

Transaction costs can be divided into three broad categories, namely search costs and information costs such as in determining that the goods needed are available in the market, which have the lowest price, and others. Bargaining and decision costs are those required to reach an acceptable agreement with the other party in the transaction, conclude the appropriate contract, and so on. Policing and law enforcement costs are the costs of ensuring the other party sticks to the terms of the contract, and takes appropriate action (often through the legal system) if this is not the case.

The term "transaction costs" is often thought to have been coined by Ronald Coase, who used it to develop a theoretical framework for predicting when certain economic tasks would be performed by firms, and when those tasks would be performed in the marketplace. However, the term did not actually exist in his early work until the 1970s. Although he did not make any specific terms, Coase did discuss "costs using the pricing mechanism" in his 1937 paper The Nature of the Firm. Where he first discusses the concept of transaction costs, and refers to "Market Transaction Costs" in his major work, The Problem of Social Cost. The term "Transaction Cost" itself can be traced back to 1950s monetary economics literature, 


\subsection{Theory of Reasoned Action and Theory of Planned Behavior}

The study of behavioral finance began to develop since 1900. Behavioral finance is a response to standard finance which focuses on a rational and static approach, while behavioral finance is more about seeing financial actors as human behavior. Pompian provides a complete discussion of behavioral finance in his book, Behavioral Finance and Wealth Management. This book is a guide to understanding irrational investor behavior and creating individual portfolio investors through irrational behavior.

Among the theories included in behavioral finance are Theory of Reasoned Action and Theory of Planned Behavior, these two theories are used to predict user or bank customer behavior related to reactions when faced with choices in purchasing products or services. Theory of reasoned action aims to explain the relationship between attitudes and behavior in human action. It is mainly used to predict how individuals will behave based on their preexisting attitudes and behavioral intentions. Individual decisions to engage in certain behaviors are based on the results the individual expects as a result of that behavior. Developed by Martin Fishbein and Icek Ajzen in 1967, this theory stems from previous research in the fields of social psychology, persuasion models, and attitude theory.

The main purpose of Theory of reasoned action is to understand the voluntary behavior of an individual by examining the underlying underlying motivation to perform an action. Theory of reasoned actionstates that a person's intention to perform a behavior is the main predictor of whether they actually do the behavior or not. In addition, the normative component (i.e. the social norms surrounding the action) also contributes to whether the person will actually perform the behavior or not. According to the theory, the intention to perform a certain behavior precedes the actual behavior. These intentions are known as behavioral intentions and arise as a result of the belief that performing the behavior will lead to a certain outcome. Behavioral intentions are important to theory because they are "determined by attitudes toward subjective behavior and norms." The theory of reasoned action suggests that stronger intention leads to increased effort to perform behavior.

\section{Research Methods}

This research is a combination research or mixed methods. Combined research is a research method that combines or combines quantitative methods and qualitative methods to be used jointly in a research activity, in order to obtain data that is more comprehensive, valid, reliable, and objective. Comprehensive data is complete data which is a combination of quantitative and qualitative data. Valid data are data that have a high degree of accuracy between data that actually occurs and data reported by researchers. Reliable data is data that is consistent over time and from person to person. Objective data is data that many people agree on. By using a combination method, the objectivity of the data obtained through qualitative methods that are subjective can be increased in a wider sample by means of the quantitative method.

When viewed from the object of study, this research is a combination of field research (field research) and library research (library research), namely research that relies on data obtained from in-depth interviews, journals, and research results.By using a combination method, the weaknesses found in both the quantitative and the qualitative methods are expected to be reduced or eliminated even if possible can be eliminated. 


\section{Discussion}

After conducting in-depth interviews with research informants and literature review through searching the literature related to research studies, a decomposition of the 5 problems constructed in a model can make it easier for researchers or respondents to understand the problem of implementing the Musyarakah agreement. mutanaqisah in financing home ownership in Islamic Bank Medan City.

The strategy model for implementing the Musyarakah Mutanaqisah contract on home ownership financing in Islamic Banks in Indonesia made by the Super Decisions Software can be seen in Figure 1 below.

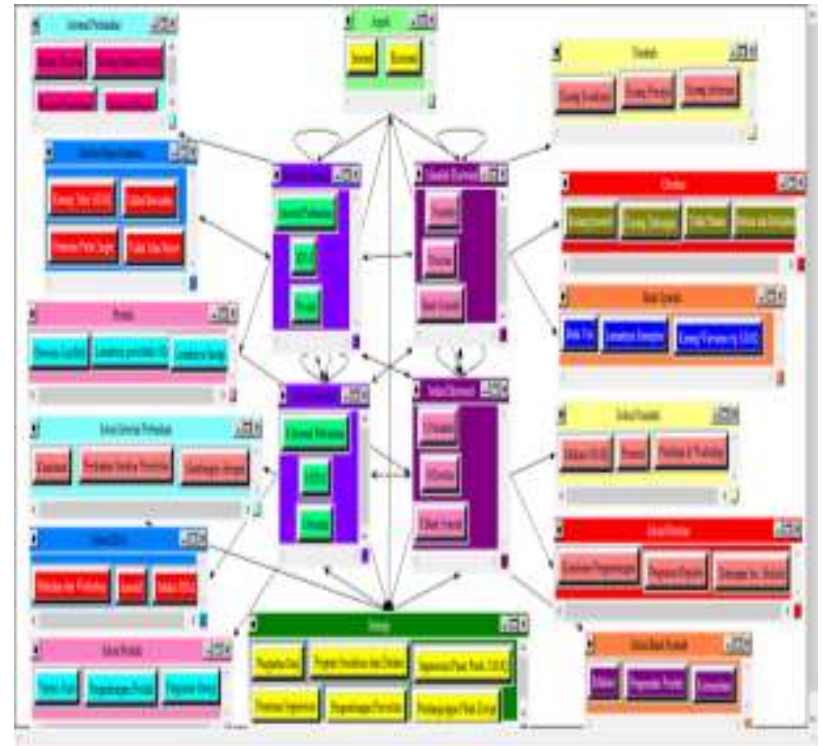

Figure 1. ANP Model Problems, Solutions, and Implementation Strategies Musyarakah Mutanaqisah Contract on Home Ownership Financing in a Sharia Bank

\subsection{Synthesis Analysis of Research Results}

Referring to the methodology used, namely the Analytic Network Process (ANP) to see the priority scale according to the Islamic banking experts and practitioners who were respondents in this study.

To see the results of the priority synthesis of each respondent can be seen in Figure 2 below:

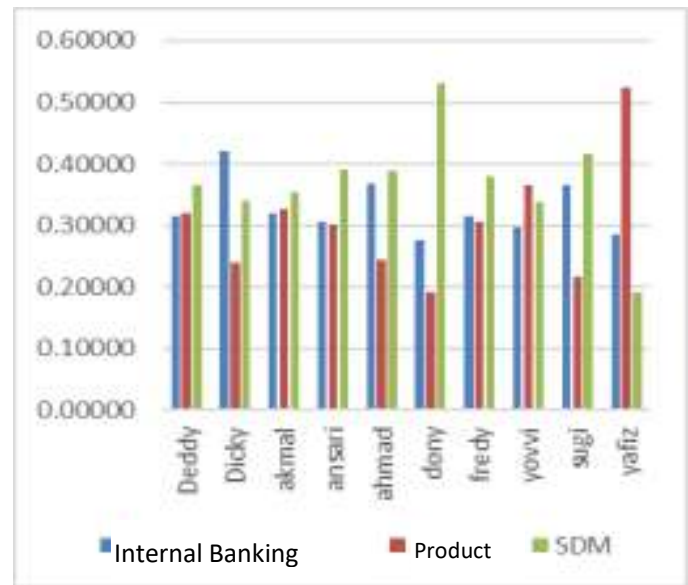

Figure 2. Synthesis Results of Priority Internal Problems based on the Value of Each Respondent 
Based on the results of data processing through Super Decision Software, the priority of internal banking problems is obtained according to the opinion of all respondents as shown in Figure 3 below:

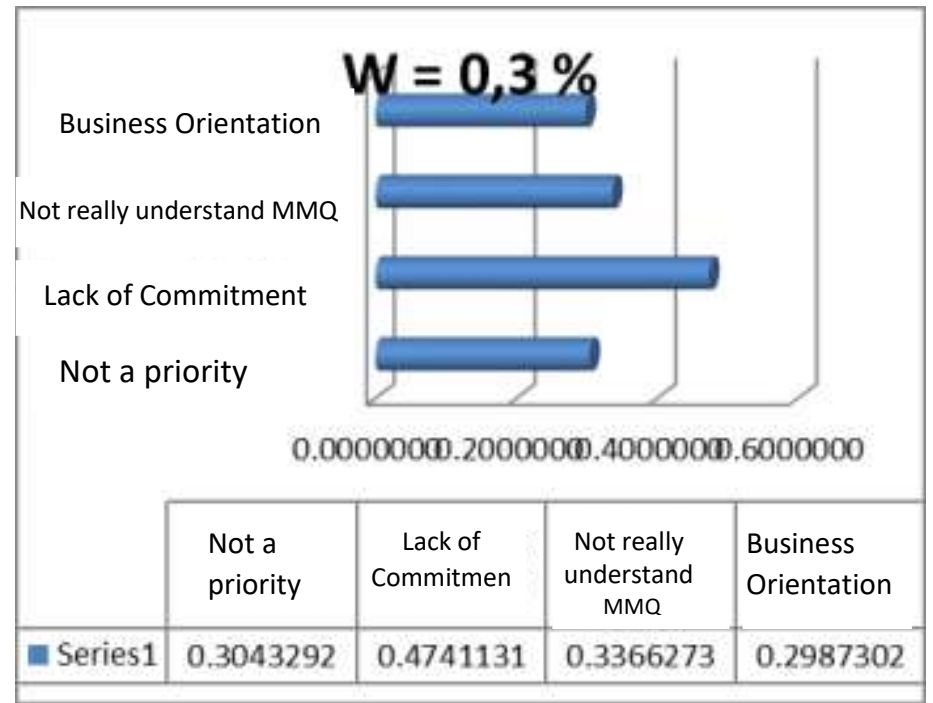

Figure 3. Synthesis of Priorities for Internal Banking Problems Based on Average Values below:

To see the results of the priority synthesis of each respondent, it can be seen in Figure 4

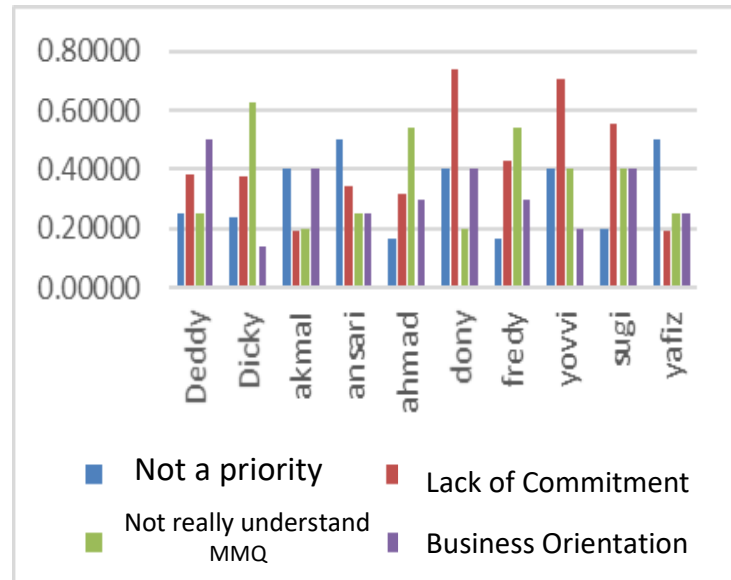

Figure 4. Results of Priority Synthesis of Internal Banking Problems Based on the Value of Each Respondent

\subsection{Internal Problem Analysis: Human Resources}

This discussion will describe the results of the synthesis on the internal problem subcluster to determine the strategy for implementing the musyarakah mutanaqisah contract on home ownership financing in Islamic Banks in Indonesia, namely the problem of human resources (HR). Based on the results of data processing through Super Decision Software, the priority of human resource problems is obtained in the opinionall respondents as shown in Figure 5 below: 


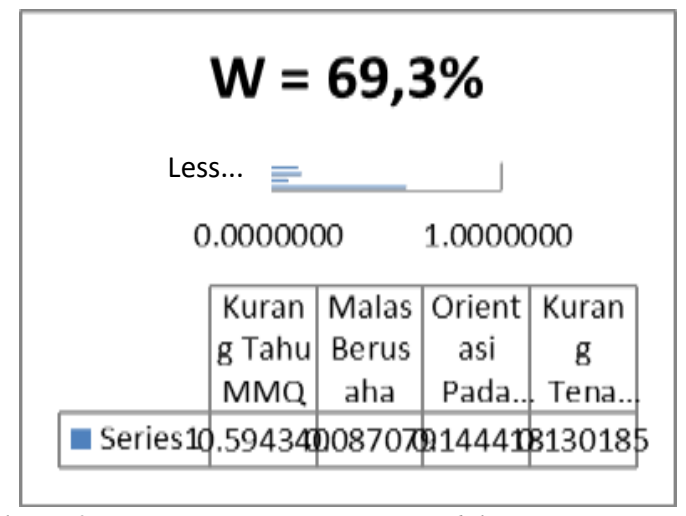

Figure 5. Synthesis Results of Human Resource Problem Priorities Based on Average Value

To see the results of the priority synthesis of each respondent, it can be seen in Figure 6 below:

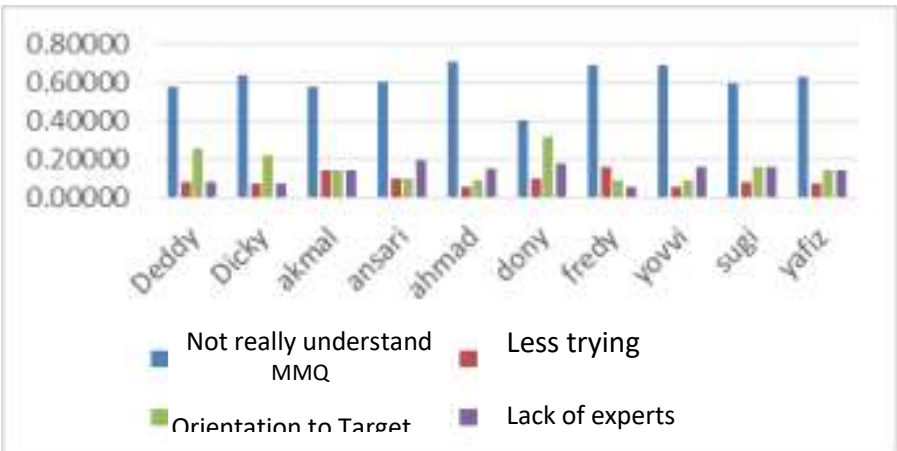

Figure 6. Synthesis Results of Human Resource Issues Priority Based on the Value of Each Respondent

Based on the results of data processing through Super Decision Software, the priority of product problems is obtained according to the opinion of all respondents as shown in Figure 7 below:

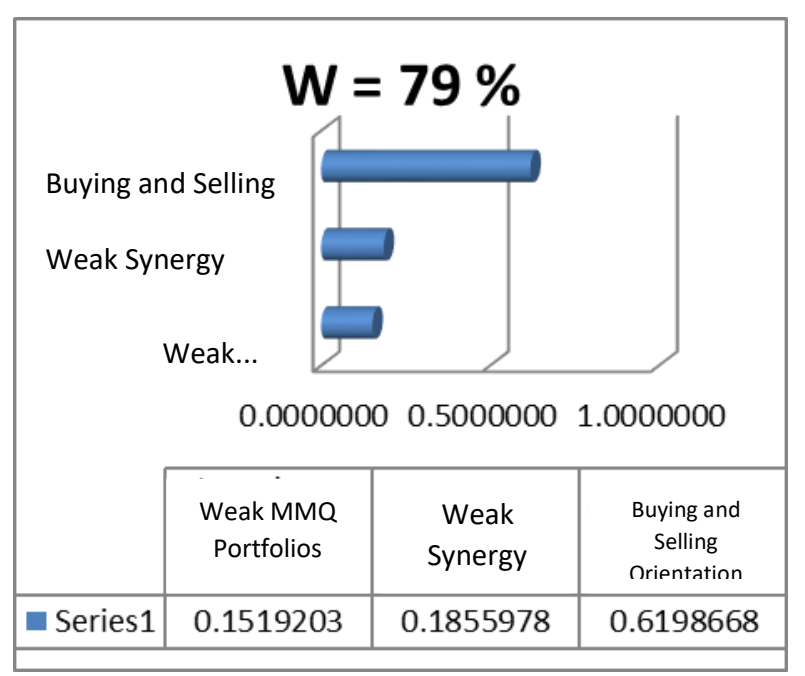

Figure 7. Synthesis Results of Product Problem Priorities

To see the results of the priority synthesis of each respondent, it can be seen in Figure 8 below: 


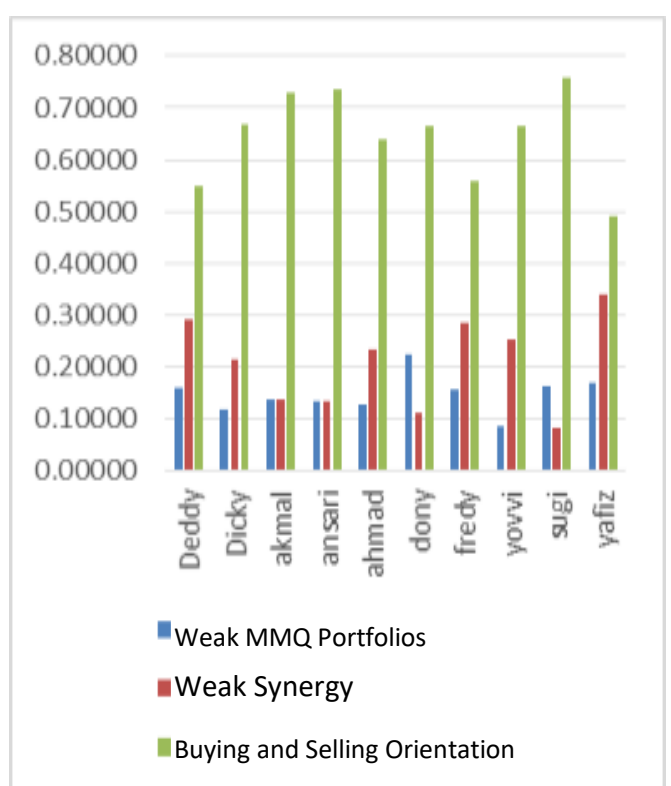

Figure 8. Synthesis Results of Product Problem Priorities

Based on the results of data processing through Super Decision Software, the priority of external problems is obtained according to the opinion of all respondents as shown in Figure 9 below:

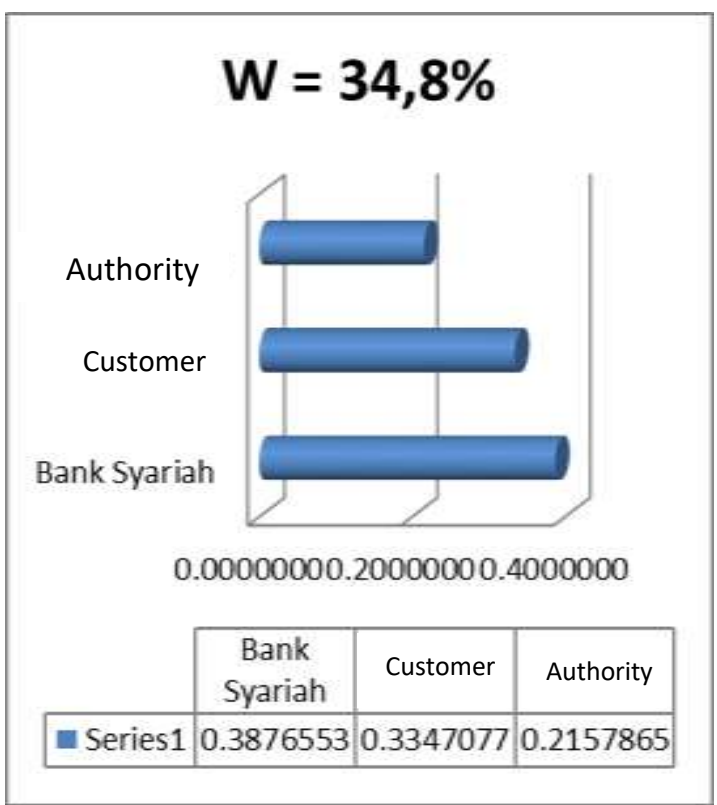

Figure 9. Synthesis Result of External Problem Priority Based on Average Value

To see the results of the priority synthesis of each respondent can be seen in Figure 10 below: 


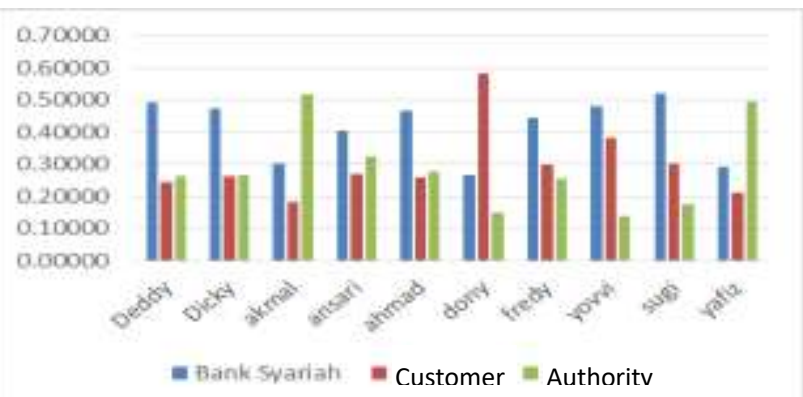

Figure 10. Synthesis Results of External Problem Priorities Based on the Value of Each Respondent

Based on the results of data processing through the Super Decision Software, the priority of Islamic banking problems is obtained according to the opinion of all respondents as shown in Figure 11 below:

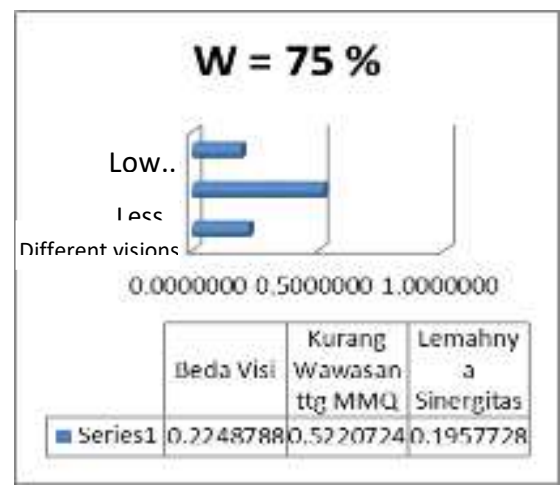

Figure 11. Results of the Priority Synthesis of Islamic Banking Problems Based on the Average Value

To see the results of the priority synthesis of each respondent, it can be seen in Figure 12 below:

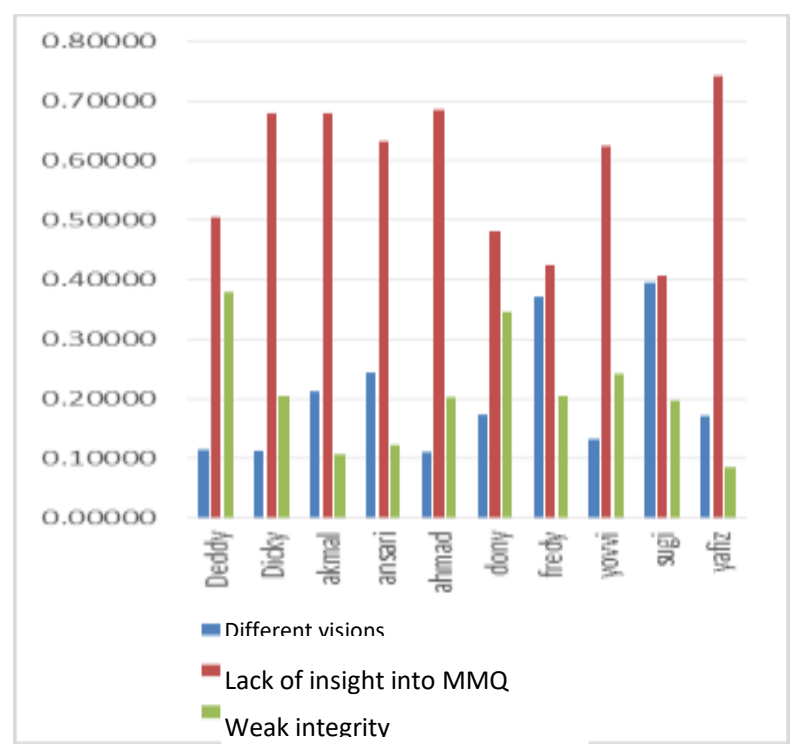

Figure 12. Results of the Priority Synthesis of Islamic Banking Problems Based on the Value of Each Respondent 


\subsection{External Problem Analysis: Customer}

This discussion will describe the results of the synthesis on the external problem sub cluster to determine the strategy for implementing the musyarakah mutanaqisah contract on home ownership financing in Islamic Banks in Indonesia, namely customer problems. Based on the results of data processing through Super Decision Software, the priority of customer problems is obtained according to the opinion of all respondents as shown in Figure 13 below:

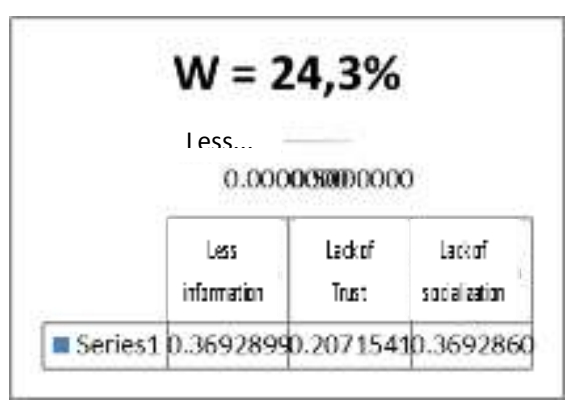

Figure 13. Synthesis Results of Customer Problem Priorities Based on Average Value

To see the results of the priority synthesis of each respondent, it can be seen in Figure 14 below:

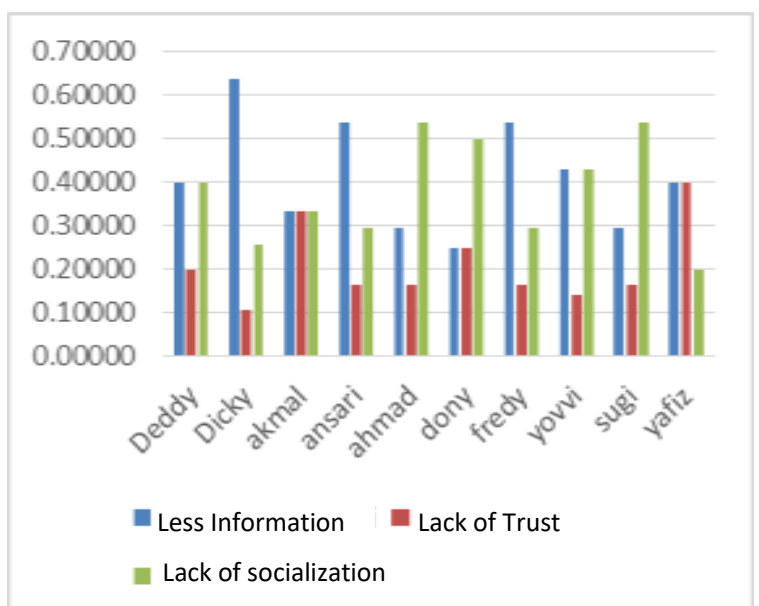

Figure 14. Synthesis Results of Priority Customer Problems Based on the Value of Each Respondent

\subsection{External Problem Analysis: Authority}

This discussion will describe the results of the synthesis on the external problem sub cluster to determine the strategy for implementing the musyarakah mutanaqisah contract on home ownership financing in Islamic Banks in Indonesia, namely the issue of authority. Based on the results of data processing through Super Decision Software, the priority of authority issues is obtained according to the opinion of all respondents as shown in Figure 15 below: 


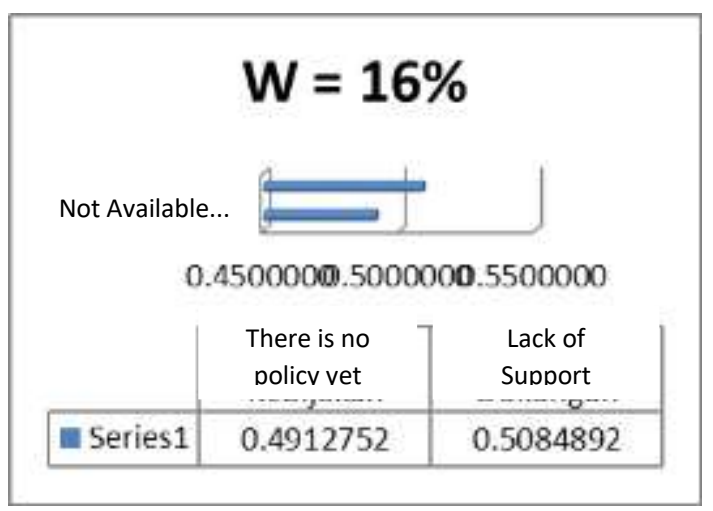

Figure 15. Synthesis Results of Authority Problems Priority Based on Average Value

Figure 16 above shows that based on the combined opinion of the respondents. To see the results of the priority synthesis of each respondent, it can be seen in Figure 16 below:

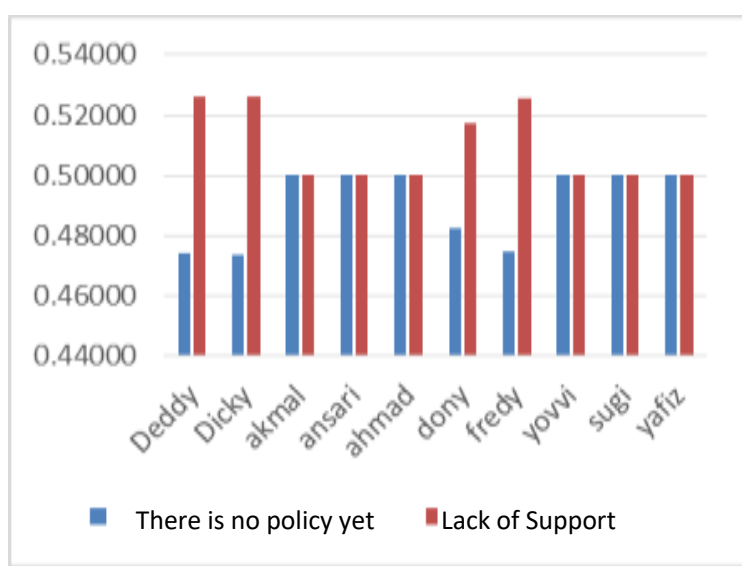

Figure 16. Synthesis Results of Authority Problem Priorities Based on the Value of Each Respondent

Based on the results of data processing through the Super Decision Software, internal solution priorities are obtained according to the opinion of all respondents as shown in Figure 17 below:

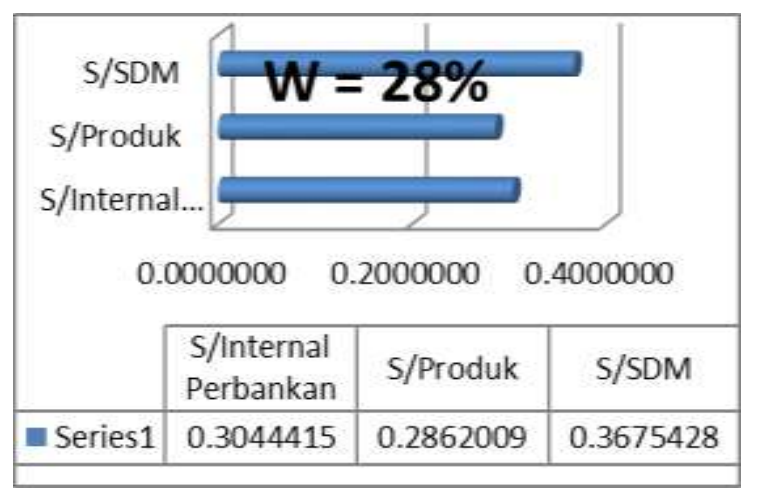

Figure 17. Synthesis Result of Internal Solution Priority Based on Average Value

To see the results of the priority synthesis of each respondent, it can be seen in Figure 18 below: 


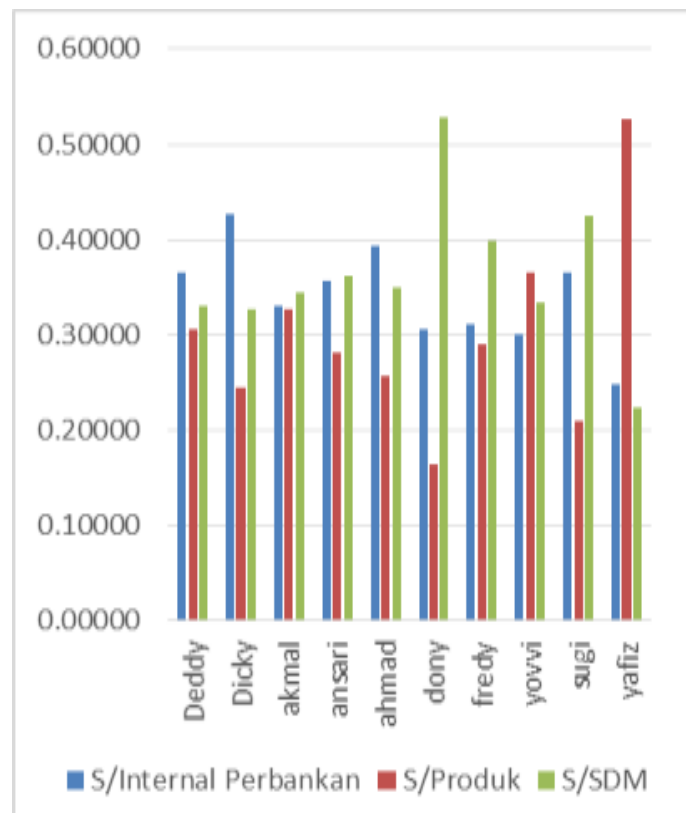

Figure 18. Synthesis Results of Internal Solution Priorities Based on the Value of Each Respondent

\subsection{Internal Solution Analysis: Internal Banking}

Based on the results of data processing through Super Decision Software, the priority for internal banking solutions is obtained according to the opinion of all respondents as shown in Figure 19 below:

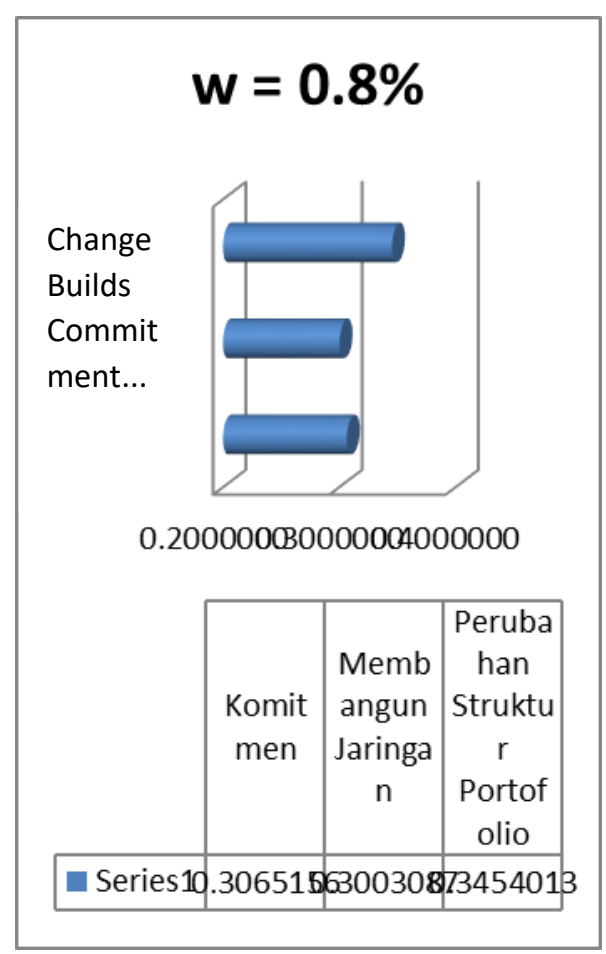

Figure 19. Results of the Priority Synthesis of Internal Banking Solutions Based on Average Values

To see the results of the priority synthesis of each respondent, it can be seen in Figure 20 below: 


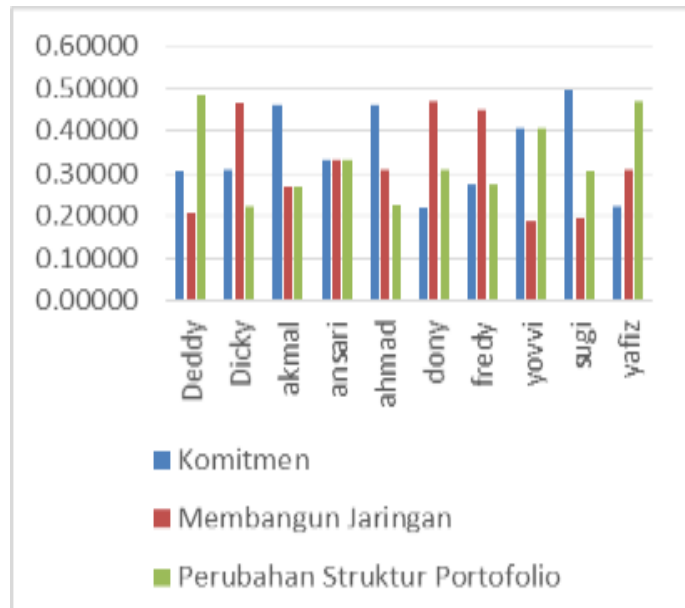

Figure 20. Results of the Priority Synthesis of Internal Banking Solutions Based on the Value of Each Respondent

Figure 20 above shows that the results of the priority synthesis per respondent show that out of 10 (ten) respondents, 3 (three) respondents answered that internal banking solutions were the most priority in determining the strategy for implementing the Musyarakah Mutanaqisah contract on home ownership financing at Islamic Banks in Indonesia is a commitment, then 3 (three) people answered that the most priority internal banking solution is building a network. Then 2 (two) people answered that the most priority internal banking solutions were changes in portfolio structure, 1 (one) respondent argued that the internal banking solutions in the form of commitment, network building and portfolio structure changes had the same priority. And 1 (one) respondent argues that the internal banking solution is a commitment, and changes in portfolio structure have the same priority in determining the strategy for implementing the musyarakah mutanaqisah contract on home ownership financing in Islamic Banks in Indonesia. This is in line with the rater agreement figure obtained, which is $0.8 \%$.

\subsection{Internal Solution Analysis: Human Resources}

This discussion will describe the results of the synthesis of the internal sub-solution cluster to determine the implementation strategy of the Musyarakah Mutanaqisah Akad on home ownership financing in Islamic Banks in Indonesia, namely the human resource (HR) solution. Based on the results of data processing through Super Decision Software, the priority of human resource (HR) solutions is obtained according to the opinion of all respondents as shown in Figure 21 below:

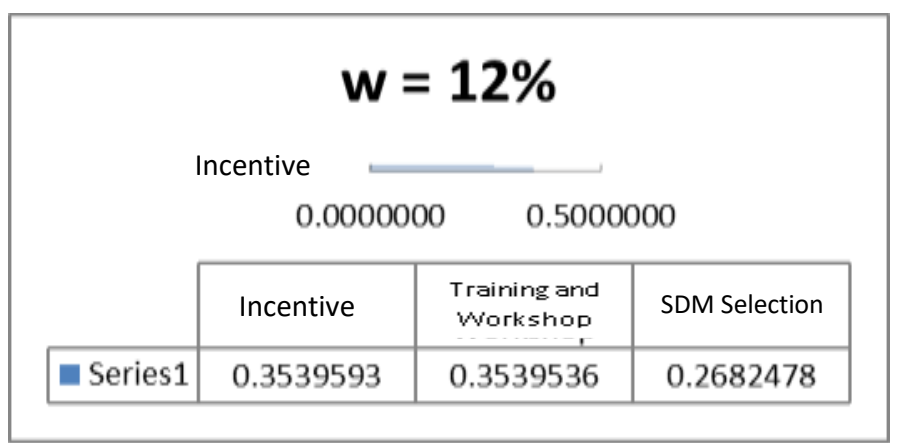

Figure 21. Synthesis Results of Human Resource Solutions Priority Based on Average Values 
To see the results of the priority synthesis of each respondent, it can be seen in Figure 22 below:

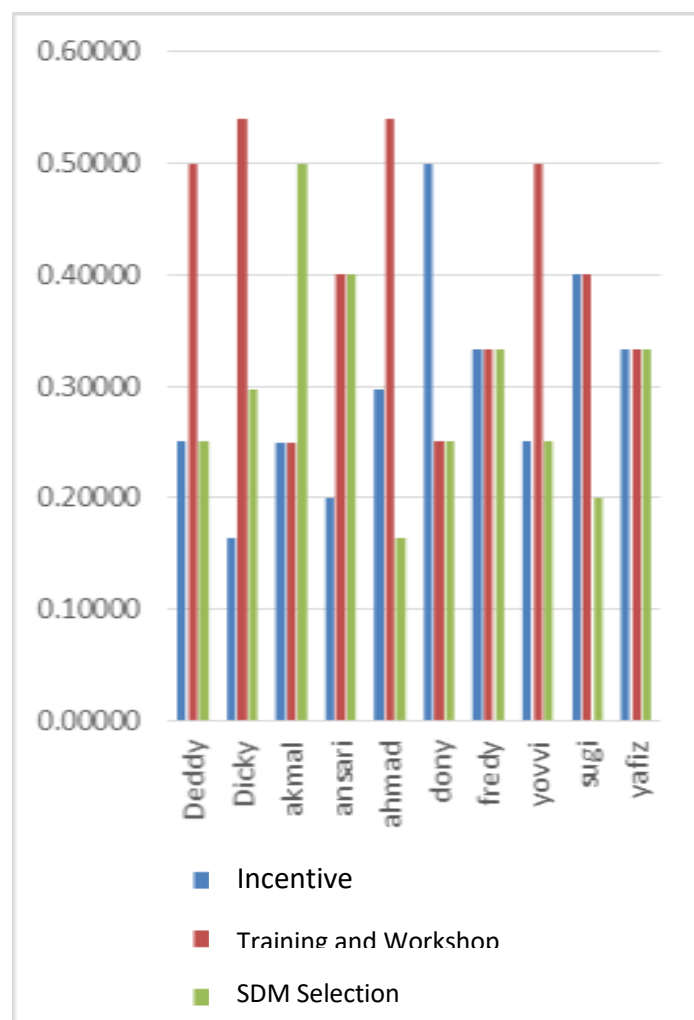

Figure 22. Synthesis Results of Human Resource Solutions Priority Based on the Value of Each Respondent

Based on the results of data processing through Super Decision Software, the priority of product solutions is obtained according to the opinion of all respondents as shown in Figure 23 below:

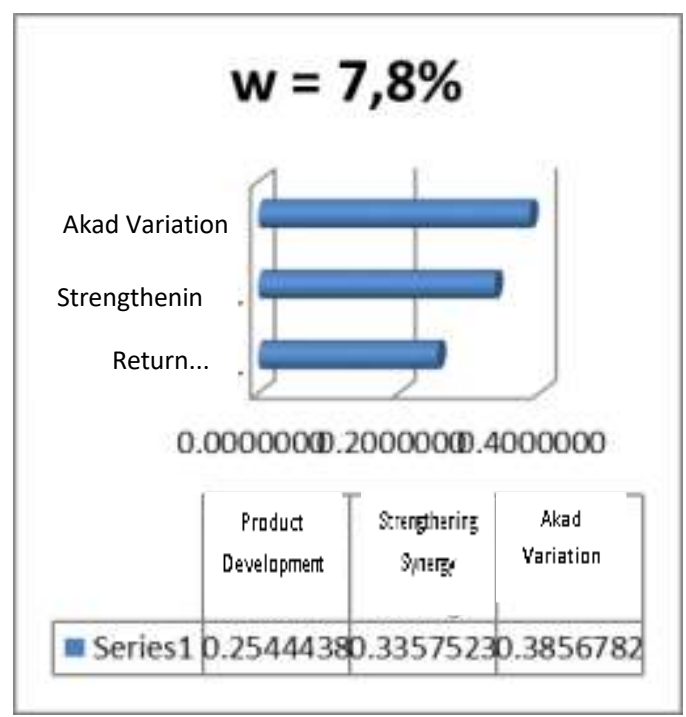

Figure 23. Synthesis Results of Product Solutions Priority Based on Average Value 
To see the results of the priority synthesis of each respondent, it can be seen in Figure 24 below:

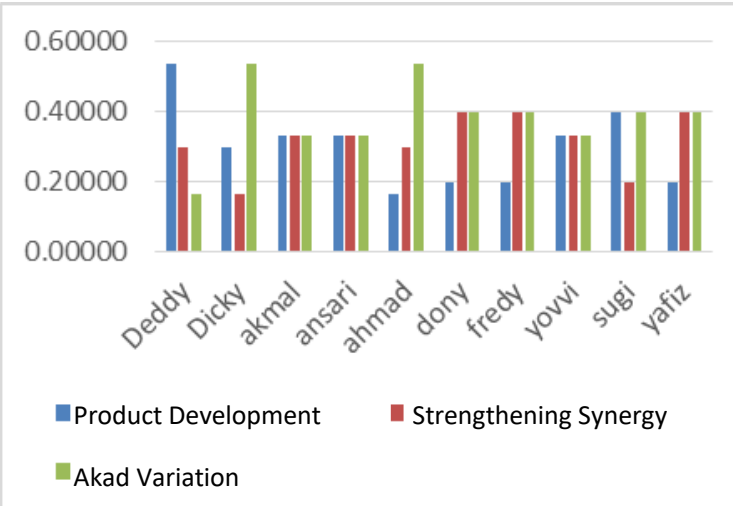

Figure 24. Synthesis Results Priority Product Solutions Based on the Value of Each Respondent

Based on the results of data processing through Super Decision Software, the priority for external solutions is obtained according to the opinion of all respondents as shown in Figure 25 below:

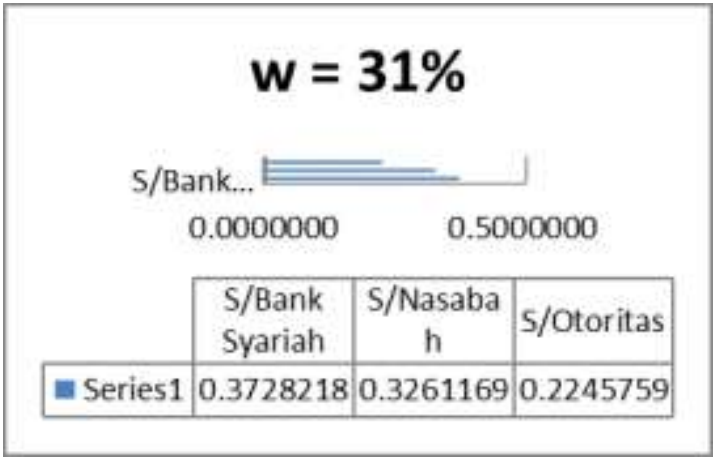

Figure 25. Synthesis of External Solution Priority Based on Average Value

To see the results of the priority synthesis of each respondent can be seen in Figure 26 below:

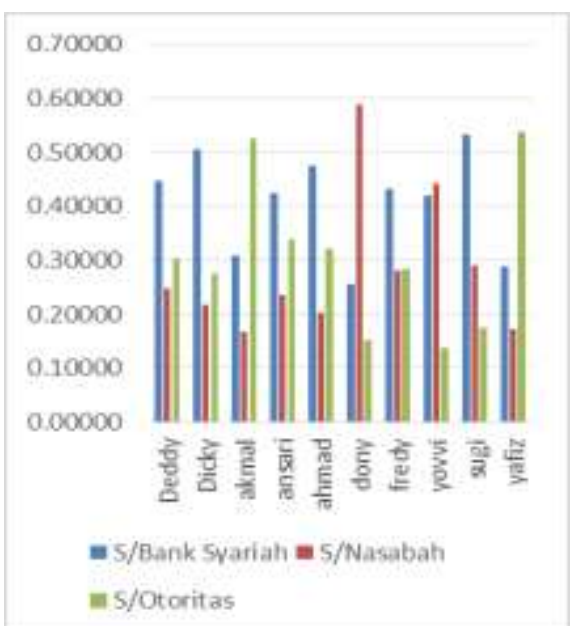

Figure 26. Synthesis Results of External Solutions Priority Based on the Value of Each Respondent 
Based on the results of data processing through Super Decision Software, the priority of customer solutions is obtained according to the opinion of all respondents as shown in Figure 27 below:

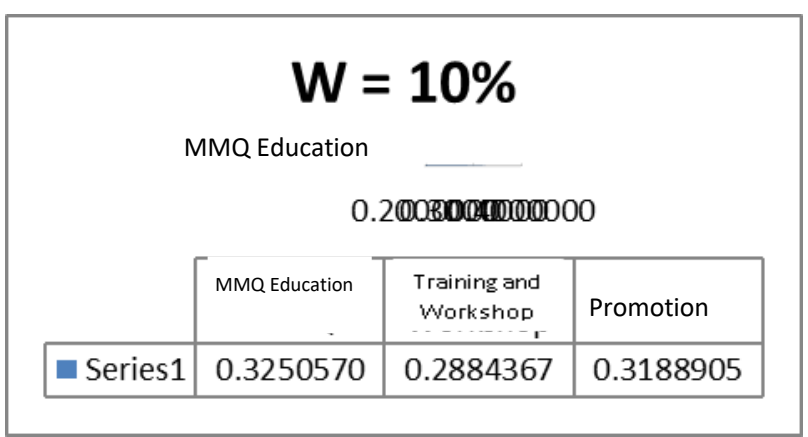

Figure 27. Synthesis Results of Customer Solutions Priority Based on Average Value

To see the results of the priority synthesis of each respondent, it can be seen in Figure 28 below:

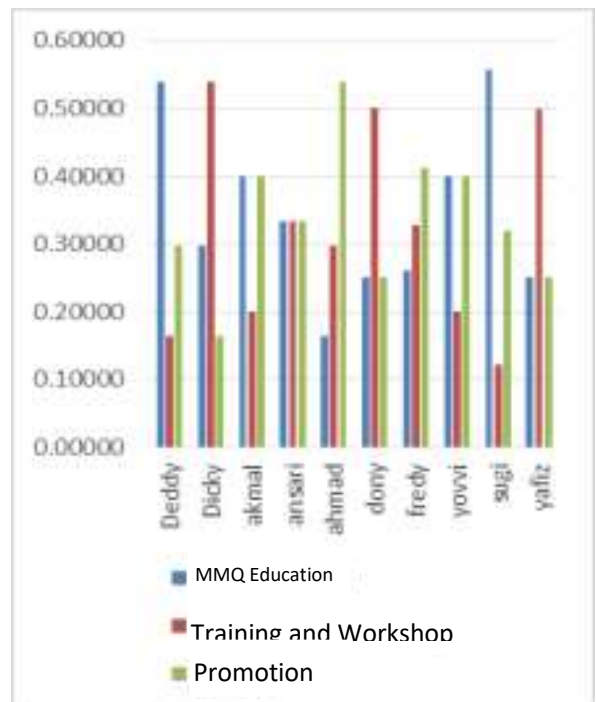

Figure 28. Synthesis Results of Customer Based Priority Solutions Value of Each Respondent

Based on the results of data processing through Super Decision Software, the priority of authority solutions is obtained according to the opinion of all respondents as shown in Figure 29 below:

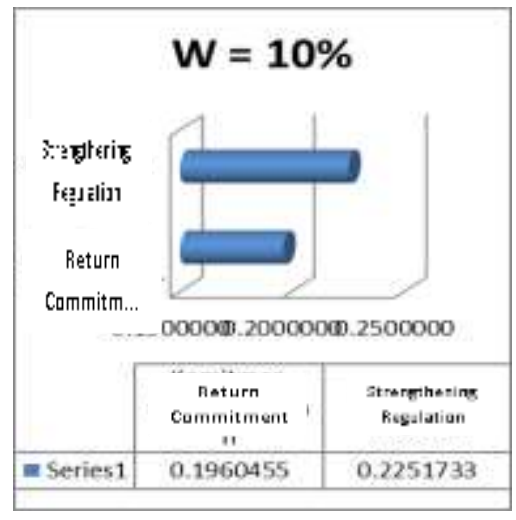

Figure 29. Synthesis Results of Authority Solutions Priority Based on Average Value 
To see the results of the priority synthesis of each respondent, it can be seen in Figure 30 below:

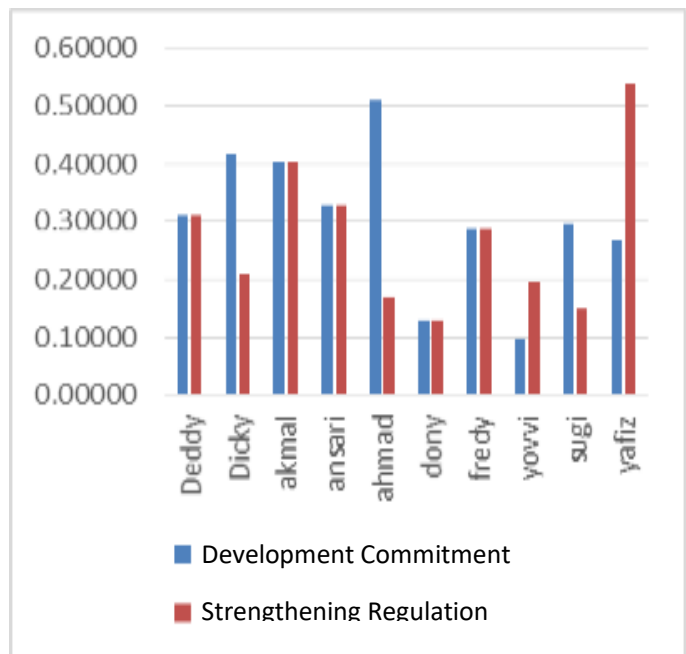

Figure 30. Synthesis Results of Authority Solutions Priority Based on the Value of Each Respondent

To see the results of the priority synthesis of each respondent, it can be seen in Figure 31 below:

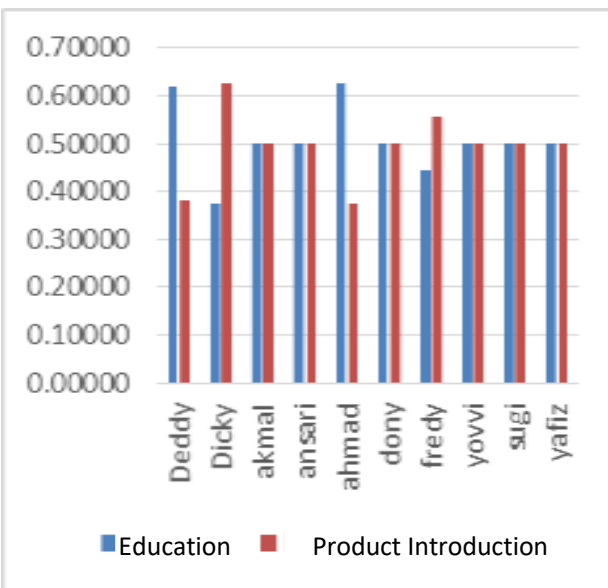

Figure 31. Results of the Priority Synthesis of Islamic Banking Solutions Based on the Value of Each Respondent

Based on the results of data processing through Super Decision Software, the strategic cluster priority is obtained according to the opinion of all respondents as shown in Figure 32 below: 


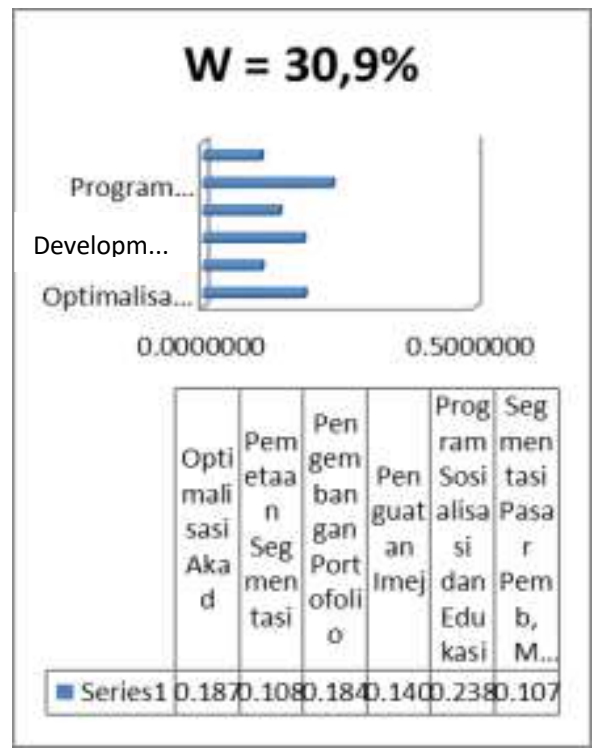

Figure 32. Synthesis of Strategy Priority Based on Average Value

To see the results of the priority synthesis of each respondent can be seen in Figure 3.36 below:

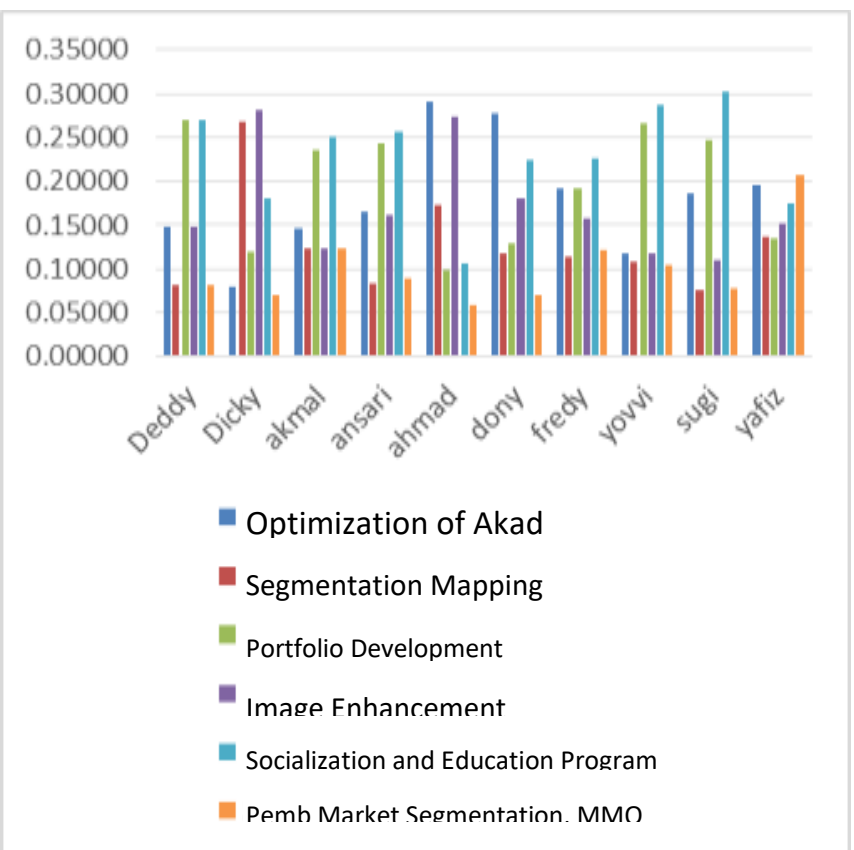

Figure 33. Synthesis of Strategy Priority Based on the Value of Each Respondent

\section{Conclusion}

The first main problem is the problem faced by Islamic Banking in the implementation of Musyarakah Mutanaqishah Financing. Based on the research results, it can be concluded that the main problems faced by Islamic banking originate from internal and external problems. Internal problems originate from internal Islamic banking (prioritized business orientation, lack of understanding of the MMQ concept, not being a priority and lack of commitment in developing MMQ) HR (Low knowledge and skills about the MMQ contract, target orientation, lack of experts and lack of effort) and products (products are still oriented towards buying and selling, weak financing portfolios in developing MMQ, Weak synergy of 
MMQ product development in Islamic banking) while external problems consist of customers (lack of knowledge about MMQ, lack of / low trust in Islamic banks, lack of information about MMQ products and portfolios), Islamic banks (differences in vision in developing sharia business, lack of knowledge about MMQ, weak perceptions in developing MMQ holistically or in synergy), authority (lack of understanding of the MMQ concept, lack of commitment in MMQ development, lack of policy support in facilitating MMQ development portfolios and lack of incentives in developing MMQ products). From the results of research conducted by researchers for internal problems, the most dominant is HR problems with Geomean results of lack of commitment in developing MMQ, lack of policy support in facilitating MMQ development portfolios and lack of incentives in developing MMQ products). From the results of research conducted by researchers for internal problems, the most dominant is HR problems with Geomean results of lack of commitment in developing MMQ, lack of policy support in facilitating MMQ development portfolios and lack of incentives in developing MMQ products). From the results of research conducted by researchers for internal problems, the most dominant is HR problems with Geomean results of0.3522262. And the most dominant of the HR problems is the low knowledge and skills about the MMQ contract with geomean results of 0.5943404. Meanwhile, the most dominant external problem was the problem of Islamic banking with a geological result of 0.3876553 . And the most dominant problem of Islamic banks is the lack of insight into the MMQ contract with a geomantic result of 0.5220724 .

\section{References}

Abdullah, R. and Ismail, AG "Al-Tawhid in relation to the economic order of microfinance institutions", Humanomics, (2014), Vol. 30 No. 4

Abdul-Rahman, A., Abdul Latif, R., Muda, R., \& Abdullah, MA Failure and Potential of Profit-loss Sharing Connection: A Perspective of New Institutional Economic (NIE) Theory. Pacific-Basin Finance Journal. 2014

Abu-Backer, HS Is there a need for legislative intervention to strengthen Shariah banking and financial instruments? Malayan Law Journal 3: clxx-clxxxix, 2002.

Agostiono, Implementation of the Van Meter and Van Horn Model Public Policy, http // kertyawitaradya.wordpre ss

Ahmad, M, "Cash waqf: historical evolution, nature and role as an alternative to riba-based financing for the grass root", Journal of Islamic Finance, 2015, Vol. 4 No. 1

Ajzen, Icek. "A Comparison of the Theory of Planned Behavior and the Theory of Reasoned Action". Personality and Social Psychology Bulletin. (February 1992)doi:10.1177 / 0146167292181001

"Martin Fishbein's Legacy: The Reasoned Action Approach". The Annals of the American Academy of Political and Social Science. 2012doi:10.1177 / 0002716211423363

Akib, Haedar and Antonius Tarigan. "The Articulation of Policy Implementation Concepts: Perspectives, Models and Measurement Criteria," Reading Journal, Volume 1 August 2008, Pepabari University Makassar, 2008

Al-Amrani, Abdullah bin Muhammad, Al-Uqud al-Maliyah al-Muraqabah, Dar Kunuz Eshbelia, Saudi Arabia, 2010

Al Jaziri Abdurrahman, Al Fiqh 'Ala al-Madzâhibul Arba'ah, Volume 3 (Lebanon: Dâr alFikri, 1994)

Al-Faruqi, IR, Al-Tawhid: Its Implications for Thought and Life, IIIT, Herndon, Virginia, 1982.

Al-Fiyruzabadi, al-Qamus al-Muhit. Juz 1. Beirūt: Dār al-Fikr, 1983. 
Al-Kamil, 'Umar Abdullah, al-Qawa'id al Fiqh al-Kubra wa Atharuha fi al-Mu'amalat alMaliyah, Jami; ah al-Azhar al-Syarif, Egypt, tt

Al-Kasani, Alauddin Abi Bakr Maswud, Bada'i as-Sana'i, Matba'at al imam, Cairo. Al Kawamelah, 1983

Basyir, Ahmad Azhar, Law Principles of Muamalat, (Yogyakarta: UII Press, 2000)

Bhambra, H. Supervisory Implications of Islamic Finance in the Current Regulatory Environment, in Archer, S. And Karim, RAA (Eds), Islamic Finance: The Regulatory Challenge, Jhon Wiley \& Sons (Asia), 2007

, Global Portfolio Optimization, Financial Analysis Journal, September 1992 (5): 28-43.

Boon Ka, Adam Ng, Shari ah and legal issues of Musharakah Mutanaqisah ', New Horizon (Official magazine of the London-based Institute of Islamic Banking and Insurance), October-December, 2009

C North, Douglass, "Transaction costs, institutions, and economic performance." San Francisco, CA: ICS Press. 1992

Campo, J. E, The Other Side of Paradise. South Carolina: University of South Carolina Press, 1991

Carl J Dahlman, "The Problem of Externality". Journal of Law and Economics. 1979, 22 (1): 141-162.doi:10.1086 / 466936

El Gamal, MA, Mutuality as an antidote to Rent-Seeking Shariah Arbitrage in Islamic Finance, Thunderbird International Business Review, Vol. 49 No. 2, 2007,

Elgari, MA Credit Risk in Islamic Banking and finance. Islamic Economic Studies, 10 (2), 2003

Endri, Problems in the Development of Corporate Sukuk in Indonesia Using the Analytical Network Process (ANP) Method, Journal of Finance and Banking, Vol. 13, No.3 September 2009

Cashmere, Banking Management (Jakarta: PT Raja Grafindo Persada, 2002)

Kautsar Riza Salman, Accounting for Islamic Banking Based on Islamic PSAKS, (Jakarta: Permata Academy, 2012)

Ministry of Public Works and Public Housing DIRECTORATE GENERAL OF HOUSING, Legal and Public Communication Division, Directorate General of Housing Provision.

Decree of the National Sharia Council of the Indonesian Ulema Council No.01 / DSN-MUI / X / 2013 concerning Guidelines for Implementing Mutanaqisah Musharaka in Financing Products

Khan, F. (2010), How 'Islamic' is Islamic banking ?, Journal of Economic Behavior and Organization, Vol. 76 No. 3

Khan, MH, Rents, Efficiency and Growth, In MH Khan \& JK Sundaram (eds.), Rents, RentSeeking and Economic Development: Theory and Evidence in Asia. Cambridge University Press, 2000

Kuen, TW (2013), Meeting the needs of homeownership, Housing the Nation: Policies, Issues and Prospects, Cagamas Holdings Berhad, Kuala Lumpur, 2013

Lastuti Abu Bakar, Tri Handayani, A Juridical Review of Housing Financing through the Musyarakah Mutanaqisah (MMQ) Agreement as an Alternative to Housing Financing in the Development of Islamic Banking Products, Journal of Islamic Economic Law, Vol. 1, No.1, May 2017 / 1438H

Mariam Jamilah Abdul Jalil, Zuriah Abdul Rahman, Investment sukuk: Comparison of the profits obtained by using Ijarah and Musharakah Mutanaqisah principles with longterm tenure",QualitativeResearch in Financial Markets, Vol. 4 Issue: 2/3https://doi.org/10.1108/17554171211252538

Markowitz, The early History of Portfolio Theory: 1600-1960 in the Financial Analysis Journal, July / August 1999: 55, 4: 5-9 
Mashoor, Abdul Latif Amirah, Al-Istithmar fi al-Iqtisad al-Islami. Al-Qahirah: Maktabat Madbouli, 1991

Maulana Hasanuddin and Jaih Mubarak, Development of the Musyarakah contract, (Jakarta, Kencana), 2012

Maulidizen, A, Islamic Finance In Theory And Practice: A Critical Analysis. Journal of Islamic Economics. 2017 Vol. 8

Mazmanian, Daniel A and Paul A. Sabatier. Implementation and Public Policy, Scott Foresman and Company, USA, 1983

McKillop, D. and Wilson, J, Credit unions as cooperative institutions: distinctiveness, performance and prospects, Social and Environmental Accounting Journal, 2015 Vol. 35 No. 2

Meera, Ahamed Kameel Mydin, \& Abdul Razak, Dzuljastri, "Home Financing through the Musharakah Mutanaqisah Contracts: Some Practical Issues", Journal of King Abdul Aziz University: Islamic Economics, Vol. 22 No. 1, 2009

Meera, Ahamed Kameel Mydin, \& Abdul Razak, Dzuljastri, "Islamic Home Financing through Musharakah Mutanaqisah and al-Bay' Bithaman Ajil Contracts: A Comparative Analysis", Review of Islamic Economics, Vol. 9, No. 2, 2000.

Mohamed-Naim, A, Purchase undertaking issues in musharakah mutanaqisah home financing. ISRA International Journal of Islamic Finance, 2011.

Mohammad Benny Hermawan, Exploration of "Islamic Residential" in Kota Pekan Baru, Journal of Architecture "Malay Architecture and Environment" Volume 1, Number 1, Pekanbaru, January 2014

Mohammad, MTS, "Theoretical and trustees' perspectives on the establishment of an Islamic social (waqf) bank", Humanomics, 2015, Vol. 31 No. 3

Mohd Razif, NF, \& Mohamad, S. Risks in contemporary finance: an assessment from an Islamic perspective [Risks in present finance: an assessment from Islamic perspectives]. In International Conference on Management ICM. Penang, Malaysia: ICM, 2011

Mohd Zaidi Md Zabri, Mustafa Omar Mohammed, "Examining the behavioral intention to participate in a Cash Waqf-Financial Cooperative-Musharakah Mutanaqisah home financing model", Managerial Finance, https://doi.org/10.1108/MF-05-2017-0189

Rehman, A. The Grand Tradition of Islamic Architecture. London: Routledge Curzon, 2002

RidaAhroum, OthmaneTouri, BoujemâaAchchab, Murabaha and Musharakah Moutanaquissah pricing: an interest-free approach, Journal of Islamic Accounting and Business Research,ISSN: 1759-0817, Publication date: 6 January 2020, Volume 11 Issue 1

Ripley, Rendal B. and Grace A. Franklin, Policy Implementation and Bureaucracy, second edition, the Dorsey Press, Chicago-Illionis, 1986

Rizal Yaya, Aji Erlangga Martawireja, Ahim Abdurahim, Contemporary Islamic Banking Accounting Theory and Practice Based on the 2013 PAPSI, (Jakarta: Salemba Empat, 2016)

Siti Fariha Muhamad \& Azira Hanani Abd Rahman, An Evaluation on Musharakah Mutanaqisah Based House Financing By Islamic Banks In Malaysia,fariha@umk.edu.my, hanani@umk.edu.my

Slamet Wiyono and Taufan Maulamin, Understanding Sharia Accounting in Indonesia, (Jakarta: Mitra Wacana Media, 2013)

Smolo, E. \& Hassan, MK The potentials of Musharakah mutanaqisah for Islamic housing finance. International Journal of Islamic and Middle Eastern Finance and Management, 4 (3), 237-258. https://doi.org/10.1108/ 17538391111166476 
, Edib, "A Theoretical Comparison between al-Bay 'Bithaman Ājil, Mushārakah Mutanāqisah Partnership and Ijārah Sukūk", Master's Dissertation, International Islamic University Malaysia, 2007.

Smolo, Edib, M. Kabir Hassan, The potentials of musharakah mutana qisah for Islamichousing finance (www.emeraldinsight.com/1753-8394.htm

Soemitra, Andri, Banks and Sharia Financial Institutions, (Jakarta: Kencana Prenada Media Group, 2009)

Solihin, D., \& Suarsa, AB Forms of Musyarakah Mutanaqisah Financing in Islamic Financial Institutions, MEA Scientific Journal (Management, Economics, \& Accounting), 3 (1), 136-160. 2019,https://doi.org/10.31955/mea.vol3.iss1.pp136-160

SOP for Financing PT. BPRS Puduarta Insani Tembung

Wael Muhammad Arabiyyat, Al-Msarif al-Islamiyah wa al-Muasasat al-Iqtisadiah. Amman: Dar al-Thaqafa, 2009

Waḥbah al-Zuhaili. 1997. Al-Fiqh Al-Islāmī Wa 'Adillatuh. Vol. 3. Beirut: Dār alFikr

Wahbah Az-Zuhaily, Al-Mu'amalat Al-Mâliyah Al-Mu'ashirah: Buhûtsu Wa Fatâwa Wa Hululu (Damascus: Dâr Al-Fikr, 2002)

Wahidullah, Adibatul Hafidlah, Jumaiyah, the Concept of the Mutanaqisah Musyarakah Akad (A Critical Study of the Implementation of the Musyarakah Agreement), Human Falah Journal of Islamic Economics and Business, Volume 6. No. July 2 - December 2019.

Wangsawidjaja, Islamic Bank Financing, (Jakarta: PT GramediaPustaka Utama, 2012)

Wasserman, N. Stewards, agents, and the founder discount: Executive compensation in new ventures. Academy of Management Journal, 2006

Webinar on excellence and application of musyarakah mutanaqisah (MMQ) financing, Agustianto Mingka (President Director of Iqtishad Consulting), May 29, 2020

Zubair Hasan, Mortgage Contracts in Islamic Home Finance: Musharakah Mutanaqisah Program vs. Zubair Diminishing Balance Model1 (INCEIF: The Global University of Islamic Finance) 2007b

Rahmati, A., Mulyadi, D., and Januddin. (2018). Analysis of Low Realization For Mudharabah Financing at Muamalat Indonesia Bank, Banda Aceh. Budapest International Research and Critics Institute-Journal (BIRCI-Journal) Vol I (4): 215-223.

Saleh, A., Dalimunthe, A.H., and Lubis, F.H. (2019). Development of Banking CSR Model for Community Empowerment Slum Area in Medan City. Budapest International Research and Critics Institute-Journal (BIRCI-Journal) Vol 2 (3): 39-50.

Tarigan, N.M.R., and Setiawan, H. (2020). The Effect of Employee Competence on Increasing Employee Motivation in Sumut Bank of Sharia Unit, North Sumatera. Budapest International Research and Critics Institute-Journal (BIRCI-Journal) Vol 3 (2) 2020: 858-867. 